\title{
Walter Somerville
}

\author{
FRITS L MEIJLER*
}

We have come to see Walter Somerville and the British Heart fournal as a unity, like body and soul. When Walter Somerville took over the editorship of the British Heart fournal there was a need for a change, and this change he has brought about. Now, in 1980, the journal is one of the five leading cardiological journals in the world. It is no easy task to separate the development and progress of a scientific journal from the growth of the scientific discipline the journal is meant to cover. The seventies have certainly seen cardiology coming of age, and Great Britain with its journal has played a dominant role in that progress. Walter Somerville is now the éminence grise of British cardiology. He has represented his country on many occasions in Europe (as the British so quaintly call the European continent), in the United States, and all over the world. He has always done so in great style, so typical of his appearance and behaviour, a style which represents British cardiology and what it stands for.

The population of the world can be divided into two kinds of people: British and non-British. The same thin line can be drawn between cardiologists. To a non-British cardiologist the present atmosphere in Britain strikes one as ambivalent. After the pre- and postwar successes of British medical sciences in general and cardiology in particular, the British in their own eyes suffered from a setback because of inflation and changes in the social

*Professor of Cerdiology, State University of Utrecht, The Netherlands. and cultural climate of their country.

Because of that, our British friends in private talks are willing to admit their worries and one notices almost an apologetic attitude. At the same time they keep their heads high hoping to conceal their sense of loss that (in their own appreciation) they do not lead the world any more.

But who is to judge who are the leaders and who are the followers? More often than not leaders emerge without the bystanders noticing it. How true has this been of British cardiologists? Just to mention a few names from the recent past: Sir Thomas Lewis, Sir James MacKenzie, Sir John McMichael, Prof J P Shillingford. Walter Somerville belongs to this illustrious list, as one of the men who does indeed lead world cardiology. Now, as ever, the grandeur of a country does not lie in its military power or in its gross national product, but in the spiritual quality of its sons. With sons like Walter Somerville there is no need for worry and apologies for Britain or for British cardiology. The friends of Britain, the non-British cardiologists, wish that Walter Somerville will witness and enjoy the growth of his profession and his journal for many years to come. It is my privilege to write these lines and to thank Walter Somerville for his contributions to international cardiology of which "Europe" has had such a big share.

Requests for reprints to Professor Frits L Meijler, Academisch Ziekenhuis, 3500 CG Utrecht, Postbus 16250, The Netherlands. 